\title{
Liberal Development Strategies: An Islamic Perspective
}

\author{
Muhammad Zahid Siddique*
}

\begin{abstract}
State and policy vacuum is an unimaginable combination. State is anyhow concerned with policy making one way or another, even if it pretends to take the form of minimum or non-government intervention in the private businesses of the individuals because this is also insistence on a particular type of public policy. The nature of public policy and development strategy is ultimately linked to the public evaluation of objectives and the assessment of economic and social means. In fact public policy is a matter of attaching weights to different goals of the life. Therefore, the legitimation of a specific form of state policy is necessarily rested upon the underlying ends and values that society aims to achieve through state powers. A proper understanding of the current state of public policy for measuring economic success, both of individual and society, requires an understanding of the informational base about the ultimate values that are regarded directly relevant for making social judgment. This paper highlights two major trends of liberal development strategies-libertarianism and social democracy-and argues why religiosity must be considered an essential integral part of development, especially in a Muslim society. Neither liberal nor libertarian policy frameworks can guarantee the sustenance of religious individuality.
\end{abstract}

Keywords: GDP-Approach to development, basic needs, Human Development Index, religiosity, hodood-ullah

\section{Introduction}

No state can exist in a policy vacuum. Public policy is inescapable in one form or another, even if it pretends to take the shape of governmental non-interference because that is also demand for a particular type of public policy. The nature of development strategy relates ultimately to the public evaluation of ends and the assessment of economic and social means. It is a matter of priorities attached to different goals. Therefore, the justification of a particular type of public policy rests upon the underlying ends and values that society aims to achieve through state powers. A proper understanding of current state of public policy for measuring economic success, both of individual and society, requires a comprehensive contextualization of the informational base: information on the ultimate values that are considered directly relevant for making social judgment. 'Human Development Index' is, in fact, a social judgment on the measure of 'success of society'. We divide these social judgments into two dominant categories, i.e. GDP (may be attributed to liberals) and beyond-GDP (may be related to social democrats), and briefly discuss the information on ultimate goals that they conceptualize as relevant for measuring the success of society. We, then, discuss why religiosity must be considered an integral part of development, especially in a society.

*Muhammad Zahid Siddique is Assistant Professor of Economics in the Management Science Department of National University (FAST), Karachi 


\section{Islamic Critique of Modern Development Strategies}

Current economic theory is firmly set in the mould structured by Adam Smith. His concern was to look into factors which affect the wealth of nations and accumulation of capital considered as an end. It is this starting-bias that has played vital role in diverting economists' attention primarily towards wealth-generation and taking income distribution as secondary because wealth belongs to the nation regardless of how it is distributed among its individuals. This poverty-mild framework has taken economics to that extreme that one can receive a Ph.D. in economics without having any idea about the extent of poverty in the world or the meaning of hunger and deprivation. It was only by 1960's that a need for shift in economic paradigm from growth to basic-needs and poverty alleviation was realized. Following two sections summarize the two dominating themes.

\subsection{GDP-Approach to Measuring Development}

In the standard literature of welfare economics, social choice theory deals with the problem of aggregating individual preferences over different alternatives to construct a social welfare function so that the alternatives could be evaluated in terms of their welfare for the society. The social judgment, in this approach, is founded on the principle of assessing states and decisions in terms of individual preferences and values. The preferences of individuals are seen only as desires for consumption activities (both as consumer of goods and as supplier of inputs) based on voluntary exchange. Moreover, the fact that 'utility functions', based on these preferences are hard to identify in practice, has guided standard welfare economic analysis to concentrate on market valuation of commodity holdings in assessing individual preference-fulfillment and also the social welfare (Sen, 1997).

The result of all this is the practice of judging social success and failures in terms of movements of 'real income' representing the values of commodities consumed and produced at constant prices. The advantage which was associated with 'real-income approach' for social judgments was the availability of an operational metric of weighing different commodities, i.e. market prices. Since these prices are conceptualized as outcome of the sum total of individual's tastes and talents dictated by the impersonal market mechanism, therefore these prices represent the true valuation of a commodity for making social judgments. The political demand of such a social judgment is the 'growth of capital' which is seen as an end in itself because everybody benefits from the material progress of society. ${ }^{1}$

However, Sen (1979) has argued that though this approach has the advantage of not requiring the information on different person's mental conditions, but it closes the door to the possibility of interpersonal comparisons of utilities all together. This result holds even if we assume that all individuals in the economy share the same preference and

'See Zahid and Ansari (2005) for a detailed description of necessary state policies based on this social judgment. 
make the same choice in similar circumstances. ${ }^{2}$ The practical problem with this social judgment approach lies in the diversity of human beings, that is, differences in individual circumstances (due to age, gender, special talents, disability, proneness to illness), social conditions ( prevalence of crime and sin) and violation of Hodood-ullah ${ }^{3}$ (limits set for human actions by Almighty Allah). These can make a difference in the level of satisfaction enjoyed by people even if they have the same commodity bundles. Moreover, the distributional indifference is another major drawback of real-income-growth approach, since it ignores inequalities in the distribution of income because what only matters is the sum total.

\subsection{Development beyond GDP}

These considerations shifted the emphasis of social judgment from income growth to unemployment, income distribution and basic needs approach. ${ }^{4}$ The advantage of basic need approach is that it recalls the fundamental concern of development: enhancement of human freedom by ensuring the opportunities to lead freer-life (Streeten, 1995). To Sen, people cannot be free if they do not have the resources to do what they like to do (Sen, 2001). The core of basic need social judgment is 'to favor the creation of conditions in which people have real opportunities of judging the kind of lives they would like to lead' and to focus 'particularly on people's capability to choose the lives they have reason to value' (Sen, 2001: p. 63). ${ }^{5}$ In this approach, 'the focus has to be on the freedom generated by commodities, rather than on commodities seen on their own' (2001: p. 74). Adequate nutrition and safe water, better medical services, better basic schooling, decent shelter and continuing employment are all considered as parameters to measure the 'success of society' by this social judgment approach. Since the provision of these goods cannot be ensured by the market, therefore basic needs approach see it as the primary role of state institutions to redistribute resources towards the deprived segments of the society.

\subsection{Plea for Islamicity as Development}

It is very important to note that the above social-judgments are not 'value neutral' in their contents, as it is normally disguised under the slogan of 'political liberalism'. ${ }^{6}$ For example, the use of market-price-based evaluation implies that all variables other than commodity holdings, e.g. morality, pity, etc., carry a zero direct weight in social judgment based on real-income approach. These variables can get an indirect positive weight if, and only to the extent, they are helpful to the enhancement of real incomes and

${ }^{2}$ For example, if a person gets exactly half (or one third, or one hundredth) of the utility from everycommodity bundle that another person gets, both will have the same choice behavior and identicaldemand function, but clearly not the same utility level from any commodity bundle. Technically speaking,the numerical representation of choice behaviour is not unique; each behavior can be represented bya wide set of possible utility functions. See Sen (1979) for details.

${ }^{3}$ Hodood-ullah is an Islamic terminology.

${ }^{4}$ See Streeten (1995) for a detailed discussion on these different issues.

${ }^{5}$ Sen calls it the 'Capability Approach of Justice' as opposed to utilitarian approach. Sen, in fact, triesto articulate Mehboob-ul-Haq's idea of 'Human Development Index' into his system of justice (See Sen,2001, chapter 3) Sen equates capabilities of a person with his opportunities to make use of alternative choices. ${ }^{6}$ This is Rawls' terminology. 
commodity holdings. Interestingly, there is a strong case for these variables to take on even negative weights under such a social judgment approach if they lead to the frustration of rate of capital-accumulation (the ultimate objective). Under these circumstances, the polity is supposed to take actions to delegitimize such moral sentiments (such as monkhood or faqr) to avoid threat to capital-accumulation. Similarly, even the scope of basic-need approach is too restricted to offer any weight for religious variables in social judgment and, hence, in policy making.

The fundamental error with such a social judgment approaches is the implicit exclusion of observing Hodood-ullah as the fundamental basic necessity for an individual's success; that is salvation in life hereafter. This indifference to Hodood-ullah in these social judgments divert the attention of polity to 'what we should do on the earth now' from the actual issue of 'what we have to do to reach heaven in the future' and in effect, leads to the marginalization of religious variables in social order. These social judgment approaches assume away the most important question of 'what social arrangements are most conducive for salvation of people after death' while conceptualizing the problem of 'what are the best social arrangements for people to live in'. In fact, these social judgments conceptualize the problem of social arrangements around the question of 'what social arrangements can allow people to live freer lives in this world, no matter whether that life leads them to hell or heaven.'

On the other hand, the concept of individual as well as social success is fundamentally related to the observance of Hodood-ullah in the Quran and Sunnah of the Prophet (SAAW). The Quran cites a number of past nations and individuals who, though, enjoyed high level of affluence and power, but, were destroyed for the sake of their disobedience of Prophets [PBUT]. ' Interestingly, the word 'Faaza' ('He succeeded') appears twice in the whole Quran in the following two verses which gives a clear indication not only about the nature of required social judgment process but also about the necessary way to achieve it:

i) 'Whosoever is saved from the (hell) fire and is entered in the heaven, he indeed is successful [he is the one who has attained the objective of his life]; and the life of this world is nothing but a deceiving comfort' [AL Quran $(3: 185)^{8}$ ].

ii) 'Whosoever obeys Allah and His Messenger [Muhammad (S.A.A.W.)]; he indeed achieves a great success' [AL Quran (33:71)].

Thus, we find strong methodological case for emphasizing the need to assign explicit evaluative weights to different components of moral sentiments and religious activities in social judgment process. The development, especially in an Islamic society, is not judged by means of rate of capital-accumulation or fulfillment of basic needs, but by

\footnotetext{
'PBUT = Peace Be Upon Them

${ }^{8}$ For this point, we would recommend reading of the verses where the Arabic word 'Fa'uz' means "success" appears. Nowhere in these verses 'success' is attached to something other than Heavens and fire, see AL Quran (4: 13), (5: 119), (9: 72 \& 89 \& 100 \& 111), (10: 62-64), (44: 51-57), (48: 5), (57: 12), (61: 12), (64: 9).
} 
the extent of observance of and deviance from Hodood-ullah as these are integral components of social judgment. The emphasis of religiosity approach that development goes far beyond basic needs because a person observing Hodood-ullah and having modest food is considered far better than a person who violates Hodood-ullah though he enjoys riches of the world is its real advantage. It opens the door to address the real objective of a man on the earth, i.e. to get salvation.

It might be objected that religiosity is multi-dimensional and cannot be subsumed under one or two indicators and that no policy maker can guarantee the achievement of all, or even the majority of these aspects. But, if, in the conventional approach, having no clear-cut criteria for defining the optimal degree of equality does not imply ignorance as to whether inequality is too great or too small and does not prevent us from judging improvements in income distribution, why should this be a hindrance in religiosity approach? Similarly, if poverty reduction programs can attract world attention and find place in 'Millennium Development Goals' (MDG's) despite the fact that poverty has a definite relative component (the perception of poverty is a function of the reference group from which the poor take their standards of what comprises the basic necessities for a decent minimum life), why the component of relativeness in religiosity based social judgment be an insurmountable barrier?

Finally, one can, in principle, claim in favor of developing religiosity indexes since Islamic practices are comparable on the basis of their relative significance, e.g. Farz (mandatory activity), Wajib (also is a mandatory activity but with less emphasis than Farz), Sunnah (the way of the Holy Prophet [SAAW $\left.{ }^{9}\right]$ ), Haram (prohibited activity), etc. Thus, we can rank different Islamic practices which a Muslim is supposed to perform according to their place and importance in Islam. Therefore, an activity which is regarded Farz (compulsory one) must be given higher weight than Sunnah or Mustahab (a desired activity) and so on to rank different Islamic activities. Great deal of help can be obtained in this regard from the work done by scholars in the field of Islamic jurisprudence (Usoole-Fiqh) wherein well-defined rules are derived from the Quran and Sunnah to judge the status of an Islamic injunction. ${ }^{10}$ The point here is that what policies can actively do is to create the opportunities for the maximum observance of Hodood-ullah and to facilitate their permanent dominance through institutional arrangements. Therefore, policies must be judged by the evident spread of obedience and reduction in the violation of Hodood-ullah.

The last few decades have seen an increasing trend of Islamization of social sciences among Muslim scholars [Rehman (1988), Ma'ruf (1986)]. The major attempts that are undertaken for this objective have been in the field of economics [see Ahmed and Kazim (1992), Ali (1990) and Usmani (1993)]. One important and systematic effort to measure religiosity from Islamic view point has been Divine Economics [Hamdani (2004); Hamdani and Ahmed Eatzaz (2002)]. This work suggests that like all other religions, the followers of Islam may also be categorized as religiously strong, moderate or weak. The reasons,

"SAAW stands for "Peace be upon Him and His followers" in its English translation. ${ }^{10}$ However, Siddique Zahid (2005) has discussed the limitations of this approach in an unpublished paper. 
to authors, that account for differences in their levels of religiosity are their Islamic knowledge or practices. On the basis of a number of quantitative and qualitative features, the authors have tried to develop 'religiosity-index' to rank the religiosity of individuals. However, the religiosity indices are not perfect and exhaustive and can be further extended to improve the overall explanatory power of the index.

\section{Conclusion}

There is dire need for neoclassical economic theory to be restated in order to take account of religiosity as an argument so that appropriate state policies can be justified that emerge from Islamic teachings. The conventional reservations that are often raised against the inclusion of religion as an argument in state policy are unwarranted. An Islamic state must take into account the spread of Islamic teachings if it has to be Islamic at all. 


\section{References}

1 Ahmed Ausaf and Kazim Raza (1992), 'Islamic economic system', Lectures on Islamic Economics, Islamic Research and Training Institute, Jeddah, IDB, pp. 131-139.

2 Ali, Ausaf (1990), 'In defense of and a plea for Islamic economics,' Universal Message, (June), Islamic Research Academy, Karachi, pp. 13-21.

3 Ansari, J. A. (2004) 'Rejecting freedom and progress', Jareedah, Vol. 29, pp. 47-224.

4 Cole, K. J., Cameron, J. and Edwards, C. (1983) Why Economists Disagree: The Political Economy of Economics, London: Longman.

5 Friedman, Milton (1982) Capitalism and Freedom, Chicago: University of Chicago Press.

6 Hamdani, Nisar (2004) 'Religion as a Factor in Time Allocation Problem', Ph.D. dissertation, Department of Economics, Quaid-i-Azam University, Islamabad

$7 \quad$ Hamdani, Nisar and Ahmed, Eatzaz (2002) 'Towards Divine Economics: Some Testable Propositions', The Pakistan Development Review, 41(4), Part II: 609-626

8 Ma'ruf A. Muhammad (1986) 'Towards an Islamic critique of anthropological evolutionism,' The American Journal of Islamic Social Sciences, Vol, 3, No. 1, pp. 89-108.

9 Rawls, J. (1971), A Theory of Justice, Cambridge: Harvard University Press.

10 Raymond, F. S. (1976) 'Smithian economics and its pernicious legacy', Review of Social Economy, Vol. XXXIV, No. 3, pp. 379-389.

11 Rehman, Fazlur (1988) 'Islamization of knowledge: a response', The American Journal of Islamic Social Sciences, (September), pp. 3-11.

12 Schultz, T. (1975) 'The value of the ability to deal with disequilibria', Journal of Economic Literature, (September), pp. 827-846.

13 Sen, A. K. (1979) 'The welfare basis of real income comparisons: a survey', Journal of Economic Literature, Vol. 17.

14 Sen, A. K. (1997) 'What is the point of development strategy?' Working papers of London School of Economics, Vol. 3

15 Sen, A. K. (2001) Development as Freedom, Oxford: Oxford University Press.

16 Streeten, P. (1995) 'Human development: means and ends', Pakistan Development Review, Vol. 34, No. 4 (winter), pp. 333-372.

17 Usmani, Taqi (1993) Islam aur Jadeed Maeeshat-o-Tijarat, Karachi: Dar-ul- Isha'at. 